Vol. 7, No. 1, 2021

UDC 711.424

Oksana Dyachok

\title{
SACRED IMAGE OF TERNOPIL REGION
}

\author{
PhD, Associate Professor, Department of Fine Arts, Design and Methods of Teaching \\ Ternopil Volodymyr Hnatyuk National, Ternopil \\ Pedagogical University \\ e-mail: Ternopil-oks@ukr.net \\ orcid:0000-0002-5808-6826
}

Received: 05.03.2021 / Revised: 11.04.2021 / Accepted: 13.04.2021

(C) Dyachok O., 2021

https://doi.org/10.23939/as2021.01.009

\begin{abstract}
The article highlights the stages of formation of the architecture of temple complexes in the Ternopil region, which today form the sacred image of the region. The set of sources used in the study has different origins, gives researchers information for analysis of sacred architecture in the modern Ternopil region, which can be used in further research. The source base of the study are churches of different denominations - Orthodox, Catholic, Greek Catholic, Jewish, Armenian, as well as the remains of pre-Christian complexes. Such ethnic and confessional heterogeneity, complex socio-political processes on the territory of the region have given rise to a typological diversity of temples, which differ in style, dimensional solution, decoration. The analysis of sacred complexes was carried out by the method of field surveys, historical and comparative analysis and was based on reliable archival sources, data from research institutions, reserves and publications of leading scientists.

European periodisation system was used in the analysis of the formation stages of sacred architecture: the Middle Ages, Renaissance, Reformation, Enlightenment, the period of XIX-XX centuries and the modern period. Each stage is marked by the appearance of majestic temples, which are bright dominants in the architectural space of settlements and creating a unique sacred image of the Ternopil region.

It is shown that there are almost no sacred objects of the early medieval period left in the study area, except for mounds and cave temples. The High Middle Ages are represented by single temples. The Renaissance period declares the adoption of Western European construction technology. Temples have a pronounced defence function. The Ternopil region is most vividly represented by the Baroque temples of the Enlightenment. The period of the XIX-XX centuries. marked by the search for a national style in sacred architecture. Modern temple complexes are built according to the traditional planning system, but some have modern forms.
\end{abstract}

Key words: sacred architecture, temple complexes, sacred image, architectural style.

\section{Problem statement}

The sacred architecture of the Ternopil region, which has a high degree of historical and cultural value and was formed over the centuries, is not fully explored today. At the same time, it reflects the 
course of national history, culture, art and the worldview of society. The attitude to their shrines, architectural monuments, the state of their preservation and use demonstrates the development and maturity of society.

The research is related to the scientific work of the Department of Fine Arts, Design and Methods of Teaching at the Ternopil Volodymyr Hnatyuk National Pedagogical University (topic: Spiritual Shrines of the Ternopil Region, state registration number: 0120U102295). The conducted scientific research opens the way for further scientific research in Architectural Studies.

\section{Analysis of recent research and publications}

The information in this article is based on the works of modern Ukrainian scientists. Many scientists have devoted their works to the classification, typology, and planning structure of individual sacred objects and monasteries in the Ternopil region: Rudnytsky A. and Chen L. (2006), Dyba Yu. (2001); Kryvoruchko Yu. (2006), Stankevych M. (2010), and others. Regional features of development and fortification functions of sacred structures and complexes of the Ternopil region are studied in the works of Bevz M. (2001), Hudyma A. and Ivakhiv G. (2008), Pavlyuk S. (2018), Rybchinsky A. and Khokhon M. (2015), etc. Traditions in the architecture of Ukrainian churches and issues of national identity were studied by Cherkes B. (2008), Bevz M. (2001), Hnidets R. (2015), Taras Ya. (2013), and others.

The analysis of publications showed that information about the architecture of the modern Ternopil region is not complete, and the sights of sacred art were ignored by researchers. All this proves the topicality of the study.

\section{Purpose of the article}

The purpose of this work is to highlight the stages of formation of the sacred image of cities and villages in the territory of the Ternopil region.

\section{Results and discussion}

Ternopil region is one of the richest regions in terms of cultural heritage in Ukraine. About 1.5 thousand architectural monuments on its territory are the most valuable asset of the Ukrainian people and are an identifier of nationality. The Ternopil region is also rich in sacred monuments of various faiths, which are important for world culture. They are the decoration and architectural dominants of settlements. Among them, 122 objects are included in the state register of national cultural heritage, many temple buildings and structures are protected at the local level.

The oldest archaeological sites of the Ternopil region are the remains of pre-Christian places of worship and structures, mounds, ancient settlements, ramparts, burial grounds, rock carvings, etc. Among the most famous and largest pagan sacred complexes is the Zbruch cult centre, near which in 1848 a sculpture of the Zbruch idol, presumably Svyatovyd, dated to the IX century, was found in the river. Archaeologists consider it one of the rare monuments of Slavic pre-Christian worship, which, unfortunately, was taken to Poland on May 12, 1851. Nowadays, the statue is kept in the Krakow Archaeological Museum, and its life-size copy is located in the Ternopil Regional Museum of local lore (Duda, 2004).

On the register of the Ternopil Regional State Administration there are 16 preserved cave temples. Among them is the Rukomysh cave church, cut out of a travertine rock near the village of Rukomysh, Buchatsky district. It is part of a cult complex, which also includes the Church of St. Onuphry, dated to the XVIII century. The main hall of the rock temple has an area of about $25 \mathrm{~m}^{2}$, several smaller grottoes, which, according to scientists, served as cells, are located on the north of the cave. In the recent period, the complex has been supplemented with a Way of the Cross, a swimming pool for consecrating water, sculptural compositions, stairs, etc. (Duda I., 2004). 
The oldest church in the Ternopil region of the medieval period, built during the existence of the Galician-Volhynian principality, is the stone church of the Transfer of the Relics of St. Nicholas in Zbruchansky. Architectural experts date the building to the XIV century and refer it to unique archaic monuments of sacred art with a stone altar partition (Fig. 1). Partially preserved in the Ternopil region is the rotunda church of the XII-XIII centuries in the village of Chernykhivtsi. Nowadays it is part of the Church of the Holy Trinity (1768) and serves as the church's sacristy (Dyba Ya., 2001).
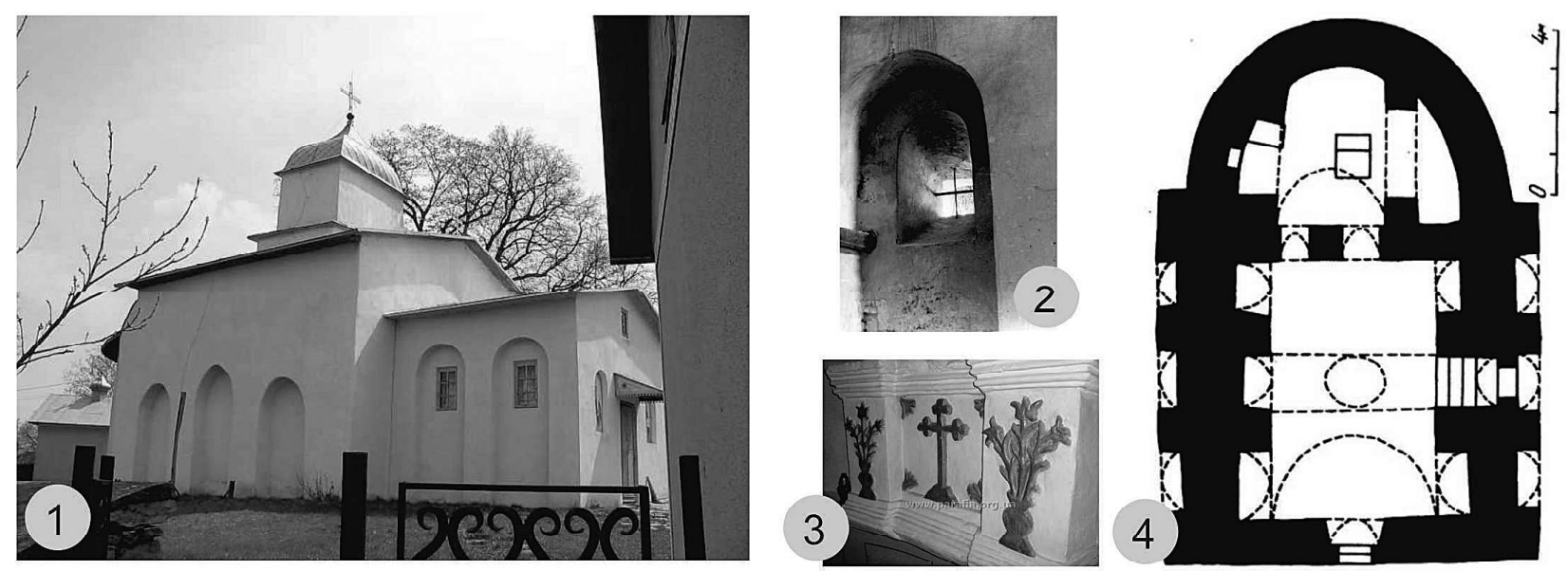

Fig. 1. St. Nicholas Church in Zbruchanskyi: 1 -view from the north-west; 2 - window niche;

3 -interior fragment; 4-plan (1,3-own photos; 2, 4-photos from the archive of the Department of Culture of Ternopil Region State Administration)

The period of revival is marked on the territory of the Ternopil region by sacred complexes, which, after the land became part of Lithuania and Poland, demonstrate the establishment of the Western European construction system with the preservation of local traditions and flavour. Complex socio-political events in this territory led to the fortification of buildings and structures, including sacred complexes. Churches of different faiths of this period have a pronounced defensive function (Rybchinsky O. and Khokhon M., 2015).

The Church of the Holy Cross is the oldest in the city of Ternopil, presumably built before 1570 . The temple has undergone numerous reconstructions and changes, so only the central part has been preserved in its original form. The architecture of the church has old Rus, Byzantine-Romanesque and Renaissance style elements and indicates the fortification function of the shrine - it has a three-tiered defensive tower-bell tower above the main entrance, high windows, large wall thickness, etc. The tridilny temple is built of sandstone and consists of a rectangular nave, a square narthex and a semicircular apse. A semicircular arch with demoulders covers the nave, a cross arch covers the narthex, and a quarter spherical arch covers the apse (Hudyma A. and Ivakhiv H., 2008).

The defence churches of the Ternopil region, built during the Reformation period, are known far beyond the borders of the region and belong to the objects of cultural heritage. They include St. George's Church in Kasperivtsi (XVI century), St. Nicholas Church (the end of XVI - beginning of XVII century) in Terebovlya, the Church of The Ascension in Vyshnivka and St. Nicholas Church in Kolodne (XVI century) and others.

The central part of the city of Ternopil is decorated with the Cathedral of the Nativity of Christ, which architectural researchers refer to as the best examples of Podillia architecture (Fig. 2). The church is three-domed (after completion, the structure is crowned with three domes, two of them are decorative), with a pronounced defensive function located near the former Kamenetsky gate and was part of the general complex for the protection of the city (Boitsun L., 2008). Reconstruction, which was carried out in 1936-1937, gave the building a modern look.

In the XV-XVI century, churches of other faiths began to appear en masse on the studied territory synagogues, Armenian churches, which are partially preserved to this day. Their thick walls, high-raised 
narrow windows, loopholes, and open combat areas indicate that in addition to their sacred function, the buildings were adapted for protection from attackers and were located near the city gates or in the central part of settlements as autonomous defence objects. Synagogues in Husyatyn, Pidhaitsi, and Kremenets have been preserved to this day, but they need to be restored. In Berezhany and Yazlovets, which were the Centers of Armenian colonization, communities are carrying out restoration work, churches remain an ornament of the historical central part of cities (Dyachok O., 2018).
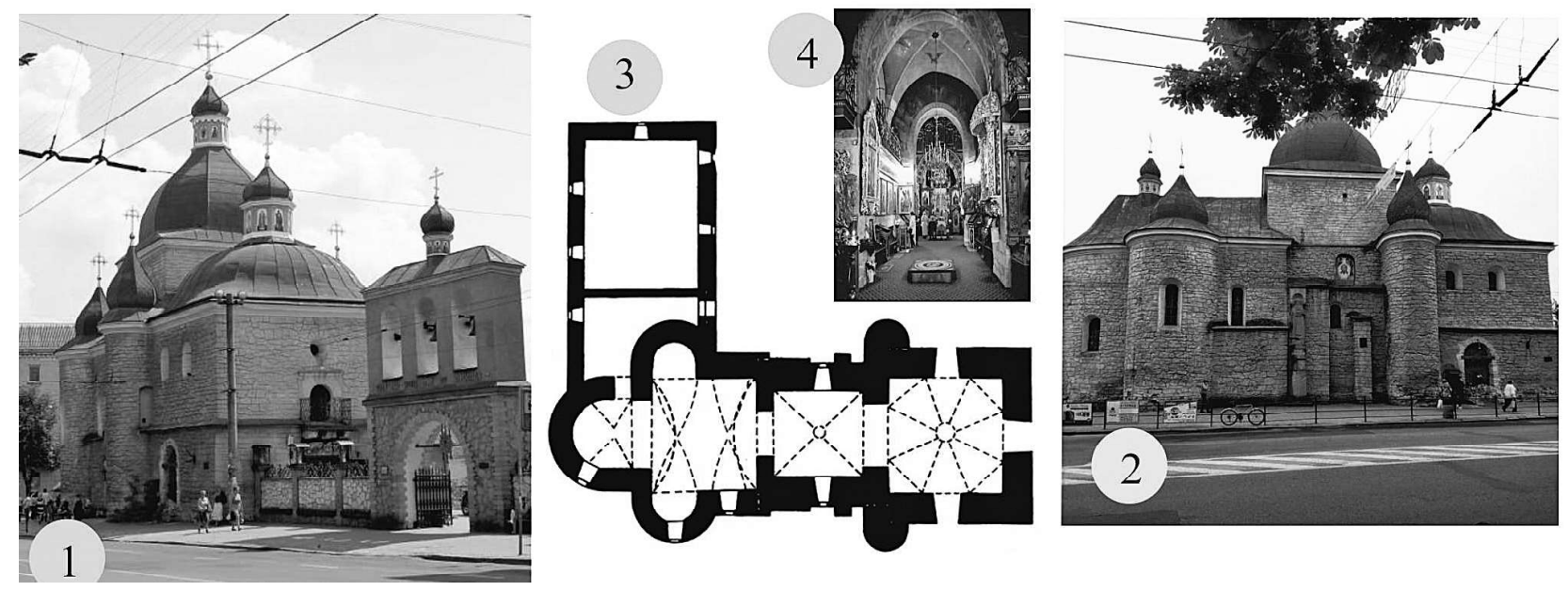

Fig. 2. Cathedral of the Nativity of Christ in Ternopil:

1 -north-western facade with Bell Tower; 2 - view from the Central Street; 3 -plan; 4 -fragment of the interior (1, 2, 4-own photos, 3 - photo from the archive of the Department of Culture of Ternopil Region State Administration)

In the second half of the XVII century, stone construction was carried out on the main roads of the Ternopil region according to the projects of invited foreign architects. With the support of the state, Roman Catholic churches were massively built, which had planning three-dimensional forms of Gothic, made in monolithic and restrained forms, marked by monumentality and simplified nature of the architectural design. The Gothic influence is reflected in the neural arches, in the proportions and shapes of windows and buttresses. Facades dissected by pilasters, frames, high external cornices indicate Renaissance motifs (Bevz, 2001).

The Ternopil region is most vividly represented by Baroque churches built in the XVII-XVIII centuries during the Enlightenment under the influence of European culture according to the projects of certified Austrian, Polish and Ukrainian architects. Among the most significant Baroque churches, there are the Ternopil Ensemble of the Dominican Monastery (1749-1779) (Fig. 3), churches of Berezhany: the Church of the Holy Trinity (1768) and the complex of the Armenian Church of St. Gregory (1764), Buchach shrines: Church of the Intercession (1755-1764), Church of the Assumption of the Virgin Mary (1761-1763), Church of the monastery of the Exaltation of the Holy Cross, baroque sacred complexes of Kremenets, Trinity Church of Mykulynets (1779) (Bilokin, S. I., 2009; Diachok O. M., 2017; Pavliuk, S. P., 2018; Stankevych, M. Ie., 2010). One of the greatest Baroque churches in Ukraine is the Church of the Assumption of the Blessed Virgin Mary in the Pochaevska Lavra, built in 1771-1783 during a large-scale reconstruction of the monastery (Lukomska Z., 2015, 2017).

Temple architecture of the period of the XIX - early XX centuries in addition to stone shrines, was presented by a large number of wooden churches. Parish communities continued to build traditional threepart churches, but with a more complex configuration. However, in the part of the Ternopil region that was part of the Russian Empire after the partition of Poland, churches form a separate group and contrast with authentic Ukrainian samples. Rebuilt or built according to synodal models, the shrines acquired OrthodoxRussian features and became an expression of the colonial policy of Tsarist Russia. The image of the Ukrainian Church was replaced with a Russian one for a long time. Almost no Catholic churches were built on this territory (Dyachok O., 2018). 

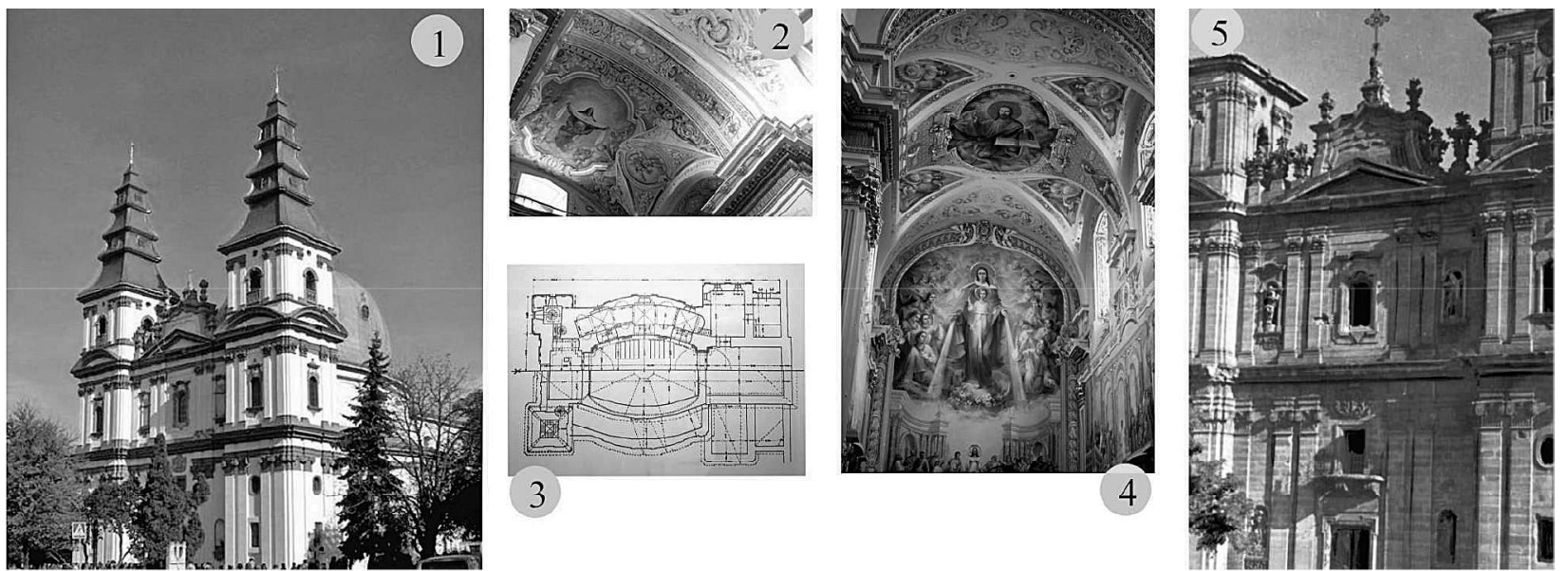

Fig. 3. The architectural complex of the Ternopil Dominican monastery:

1 -general view; 2, 4 -Modern Painting of the temple (1,2, 4-own photos); 3 - Plan; 5 -old postcard

(3,5-photo from the archive of the Department of Culture of Ternopil Region State Administration)

In the second half of the XIX century, the style of historicism was widespread on the territory of the region. Temples of different faiths reflected the best features of past eras and national architectural traditions (Linda S., 2013). Roman Catholic churches marked by stylistic diversity (built in neoRomanesque, neo-Gothic, with Baroque and Classicist features) mostly remained basilic, the western facade was crowned with one or two towers. In the territory that was part of the Austro-Hungarian Empire, the national and social rise led to the search for own identity and national style in the architecture of churches (Obidniak M., 2004; Taras Ya, 2013; Cherkes B., 2008). Lviv architects such as S. Havryshkevych, Lev and Ivan Levynskyi, Vasyli and Yevhen Nahirnyi, R. Hrytsay, O. Lushpynskyi, Ya. Rudnytskyi, M. Shashkevych left Ukraine a legacy of churches that were fundamentally different from Western Catholic churches and pointed to the image of the Ukrainian authentic church (Lev Kh., Slobodian V. and Filevych N., 2013, 2015; Cherkes b. and Hrytsiuk L., 2000) (Fig. 4).
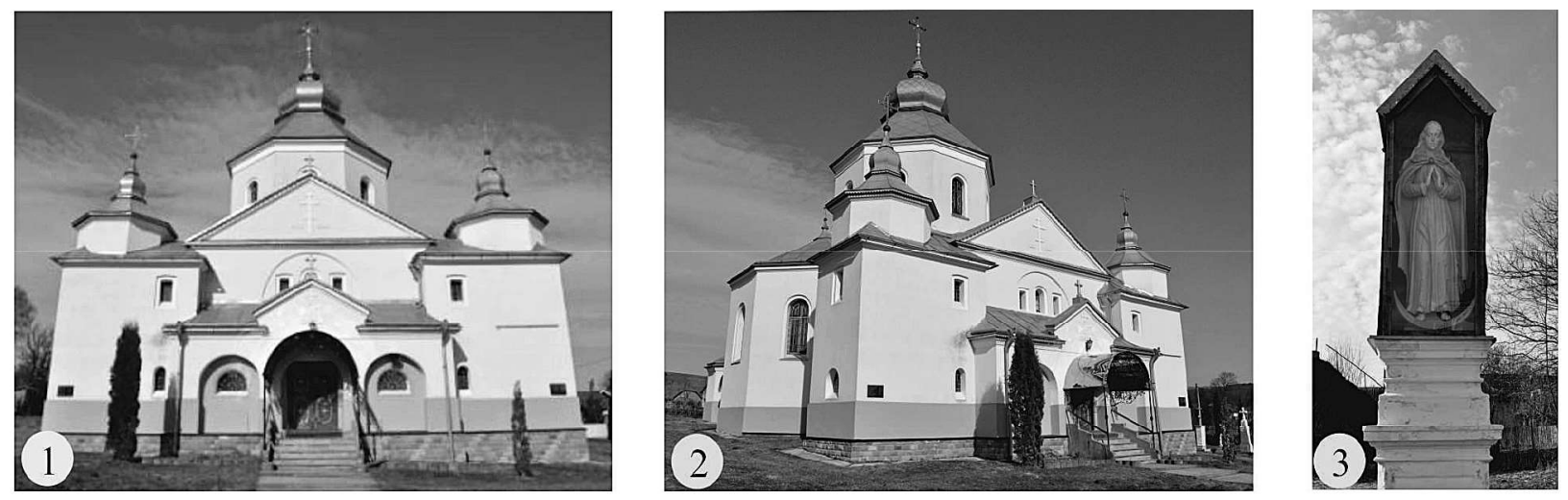

Fig. 4. Church of The Assumption of the Blessed Virgin Mary. The Virgin in the village of Verbiv (arch. O. Lushpynsky):

1,2 - general view of the church; 3 - figure of the Mother of God in the courtyard of the church (1-3-own photos)

Any experiments in sacred architecture were interrupted with the coming of Soviet atheist power. Shrines were turned into warehouses, factories, gyms etc., and many valuable monuments were destroyed. Only with the declaration of independence did large-scale construction and restoration of churches begin. A majestic temple complex of the Mary's Spiritual Center in the village of Zarvanytsia was built in the Ternopil region with donations from believers, the diaspora, state authorities, and the public. The main church of the complex is the Cathedral of the Mother of God inZarvanytsia (arch. M. Netrybyak). The architectonics of the temple indicate continuity and tradition in temple construction. The temple is crowned 
with domes that have modernized forms, the project uses modern building structures and techniques (Diachok O. M. and Datsiuk N. M., 2018). In August 2018, the Mary's Center was named and consecrated as "Ukrainian Jerusalem" - a new complex that includes copies of the largest monuments of the Holy Land.

Some temples built after 1995 are marked by the search for modern forms and techniques in construction. Modern facade plastic is usually superimposed on the traditional layout system. Among such churches is the Church of St. Peter, designed by the Ternopil architect S. Hora for the Franciscan monastery complex in Ternopil (Diachok O. M., 2018 a). Modern forms are also reflected in the Ternopil Church of God's Mercy of the Virgin Mary of Tireless Help - the highest church in the city. Architect I. Chuliy managed to emphasize the Roman Catholic affiliation of the church with modern forms. The combination of traditional layout with an original three-dimensional solution is the Ternopil Church of St. Volodymyr and Olha, designed by architect D. Chepil. It should be noted that in small towns and villages of the Ternopil region, more traditional temple buildings predominate (Diachok O. M., 2018 a).

The newest church in the Pochaev Lavra complex is the Cathedral of the Transfiguration of the Lord, designed by Kharkiv architect V. Novhorodov in 2010-2013 (Diachok O. M., 2018). The artistic value and richness of the building's decoration are undeniable, but the architectural solution causes a lot of discussion among architectural experts. It dominates the complex with its shape, size, and decoration (Fig. 5).
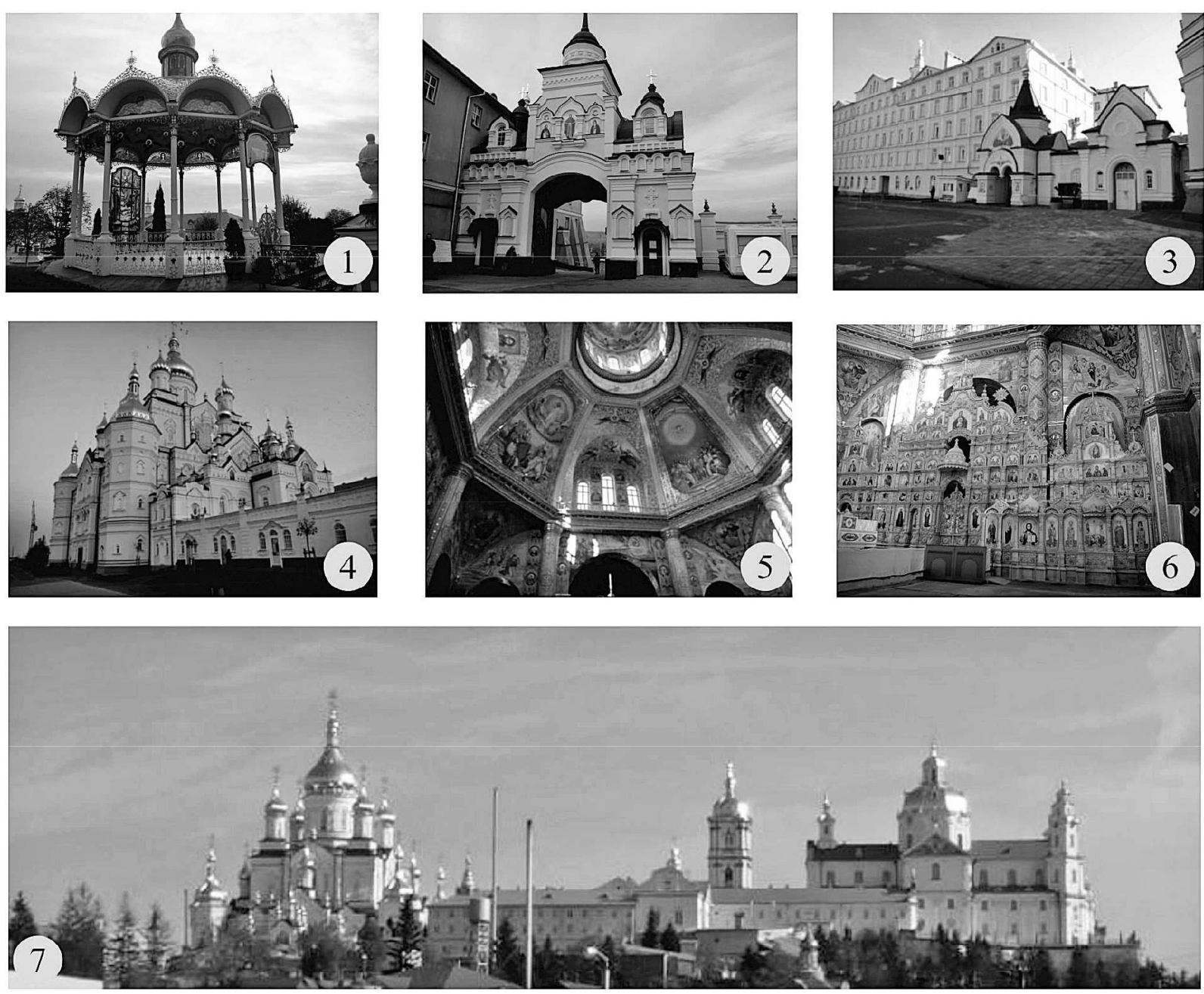

Fig. 5. Modern buildings of the Pochaev Lavra:

1 - Summer Church; 2 - Economic Gate; 3 - Hotel and underground passage; 4 - Transfiguration Cathedral; 5 - central dome of the Cathedral; 6 - iconostasis in progress; 7 - panoramic view (1-7-own photos) 


\section{Conclusions}

1. Analysis of the study shows that the sacred image of the Ternopil region was formed over the centuries. Heterogeneity of ethnic composition, confessional differences, socio-political transformations have led to a variety of religious buildings that are decorations and architectural dominants in the architectural image of historical cities. At each historical stage of the formation of sacred complexes, temples differ in their three-dimensional and constructive solution, style, decoration etc.

2. The Western European construction system took place during the period of revival after the entry of the Lands of Ternopil region into foreign states and the transition of the united kingdom to the Catholic faith. This period left behind temples with Byzantine-Romanesque forms, stylistically combined with gothic elements.

3. During the Reformation period, Roman Catholic churches were massively built, which had schemes, architectural and structural forms of Gothic architecture. Jewish and Armenian communities created their churches following their canons and traditions. Common to the shrines of all confessional communities was the combination of cult and fortification functions.

4. During the Enlightenment, majestic baroque complexes were created on the territory of the modern Ternopil region as a result of the construction and major alterations of existing shrines

5. In the period of the XIX - early XX centuries, in the territories divided between the two empires, large-scale construction of stone churches was carried out according to the projects of Western European and Russian architects and differed stylistically. After 1939, the construction of churches stopped, the revival of church construction and the reconstruction of shrines distorted by the Soviet government began with the independence of Ukraine.

\section{References}

Bevz, M., 2001. Historical cities of Galicia: problems of study and preservation. Zapysky Naukovoho Tovarystva im. Shechenka. Pratsi Komisii arkhitektury ta mistobuduvannia, 241. S. 84-112.

Bilokin, S. I., 2009. Kremenets Holy - Bohoiavlenskyi monastery. V: V. A. Smolii, hol. red. Entsyklopediia istorii Ukrainy. T. 5. Kyiv : Naukova dumka. S. 318.

Boitsun, L., 2008. Dominican church in Ternopil. V: H. Yavorskyi, B. Melnychuk, M. Onyskiv ta in., red. Ternopilskyi entsyklopedychnyi slovnyk. T. 3. Ternopil : Zbruch. S. 521.

Hlubish, O. (otets) ta Shpodarunok, N., 2006. Zarvanytsia. Ternopil. Lviv : Piramida.

Hudyma, A. ta Ivakhiv, H., 2008. Rizdva Khrystovoho Tserkva (Serednia). V: H. Yavorskyi, B. Melnychuk, M. Onyskiv ta in., red. Ternopilskyi entsyklopedychnyi slovnyk. T. 3. Ternopil : Zbruch. S. 18-183.

Hnidets, R. B., 2015. National identity of architecture of Ukrainian churches in the tradition and innovation of their expression. Visnyk Natsionalnoho universytetu "Lvivska politekhnika", 836. Arkhitektura. S. 168-175.

Dyba, Yu., 2001. Two little-known rotundas of the princely era. Zapysky Naukovoho tovarystva im. Shevchenka. 241. S. 248-274.

Duda, I., 2004. Zbrutskyi idol. V: H. Yavorskyi, B. Melnychuk, M. Onyskiv ta in., red. Ternopilskyi encyclopedic dictionary. T. 1. Ternopil : Zbruch. S. 640.

Diachok O. M. ta Datsiuk N. M., 2018. Mykhailo Netrybiak in the sacred space of Ternopil (25 - litnii tvorchyi vnesok fakultetu mystetstv.) Ternopil, TNPU. S. 396-407.

Diachok O. M., 2017. Sacred monuments of urban planning and architecture in the process of forming the space of the city of Kremenets. Suchasni problemy arkhitektury ta mistobuduvannia: nauk.tekhn.zbirnyk. K. : KNUBA, 49. S . 74-81.

Diachok O. M., 2018 a. Ternopil architects in the process of reviving the sacred construction of Ukraine. Suchasni problemy arkhitektury ta mistobuduvannia: nauk.tekhn.zbirnyk. K. : KNUBA, 51. S. 26-34.

Diachok O. M., 2018 b. Historical stages of formation and development of architecture of sacred buildings of Ternopil region. Arkhitekturnyi visnyk KNUBA : zb. nauk.-vyrobn. K. : KNUBA, 16. S. 98-108.

Kryvoruchko, Yu. I., 2006. Canonicity and creativity in sacred architecture. Visnyk Natsionalnoho universytetu "Lvivska politekhnika", 568. Arkhitektura. S. 27-46.

Lev, Kh., Slobodian, V. ta Filevych N., 2013. 100 churches of Nagorny. Ch. 1: tserkvy Vasylia Nahirnoho. Lviv, b.v.

Lev, Kh., Slobodian, V., Filevych, N., 2015. 100 churches of Nagorny. Ch. 2: tserkvy Yevhena Nahirnoho. Lviv, b.v.

Lukomska, Z., 2015. Implementation of baroque urban traditions on the example of the city of Mykulyntsi. Visnyk Natsionalnoho universytetu "Lvivska politekhnika", 836. Arkhitektura. S. 189-196. 
Lukomska, Z., $2017 \mathrm{v}$. Historical urban complexes of the XVII-XVIII centuries in the modern spatial planning structure of the cities of Ternopil region. Naukovyi visnyk budivnytstva, 4 (90). S. 42-48.

Linda, S. M., 2013. Historicism in the development of architecture: avtoreferat dysertatsii na zdobuttia naukovoho stupenia doktora arkhitektury 18.00.01. Natsionalnyi universytet "Lvivska politekhnika".

Obidniak, M. M., 2004. Problems of national identity in the new church architecture. Visnyk Natsionalnoho universytetu "Lvivska politekhnika", 505: Arkhitektura. S. 78-90.

Pavliuk, S. P., red., 2018. Church art of Ukraine. T. 1. Arkhitektura. Monumentalne mystetstvo. Kharkiv : Folio.

Plamenytska, O., 2001. Defensive temples of Podillya. Pamiatky Ukrainy, 1-2. S. 32-34.

Rybchynskyi, O. ta Khokhon, M., 2015. Peculiarities of the formation of the defensive fortifications of the Dominican monastery in Pidkamen. Problemy doslidzhennia, zberezhennia ta restavratsii istorychnykh fortyfikatsii, 7. S. $268-273$.

Rudnytskyi, A. M. ta Chen, L .Ia., 2008. The role of monasteries of the rank of St. Basil architecture in towns and villages in Ukraine. Visnyk Natsionalnoho universytetu "Lvivska politekhnika", 632. Arkhitektura. S. 44-51.

Stankevych, M. Ie., 2010. Buchach and surroundings. Small samples. Lviv : SKIM.

Taras, Ya., 2013. National identity in the sacred architecture of the Ukrainians of the Carpathians. Ch. 2. Hileia, 74. S. $149-152$

Chen, L.Ia., 2013. Temple and monastery complexes in the planning and spatial structure of the city of Buchach. Visnyk Natsionalnoho universytetu "Lvivska politekhnika", 757. Arkhitektura. S. 315-320.

Cherkes, B. ta Hrytsiuk, L., 2000. Architect Eugene Nagirny. V : Kh. Lev ta N. Filevych, red. Nahirni, Levy: istoriia rodyny. Lviv : b.v. S. 138.

Cherkes, B., 2008. National identity in the architecture of the city. Lviv : Vyd. Natsionalnoho universytetu "Lvivska politekhnika”, 2008.

\section{Оксана Дячок}

Канд. арх., дои. кафедри образотворчого мистеитва, дизайну та методики викладання Тернопільський начіональний педагогічний університет ім. В. Гнатюка, Тернопіль e-mail: Ternopil-oks@ukr.net orcid: 0000-0002-5808-6826

\section{САКРАЛЬНИЙ ОБРАЗ ТЕРНОПІЛЬСЬКОЇ ОБЛАСТІ}

Анотація. У статті висвітлено етапи формування архітектури храмових комплексів на Тернопільщині, які сьогодні формують сакральний образ регіону. Джерела, використані у дослідженні, мають різне походження, дають дослідникам інформацію для аналізу сакральної архітектури сучасної Тернопільської області, яка може бути використана для подальиих досліджень. Джерельною базою дослідження $\epsilon$ иеркви різних конфесій - православна, католицька, греко-католицька, єврейська, вірменська, а також залишки дохристиянських комплексів. Така етнічна та конфесійна неоднорідність, складні сочіально-політичні процеси на території регіону породили типологічне різноманіття храмів, що відрізняються стилем, розмірами, композиційним виріменням, оздобленням. Аналіз сакральних комплексів проводився методом польових обстежень, історичного та порівняльного аналізу $і$ базувався на надійних архівних джерелах, даних дослідницьких установ, заповідників та публікачіях провідних учених.

Європейська система періодизаиії була використана для аналізу стадій формування сакральної архітектури: Середньовіччя, Відродження, Реформачія, Просвітничтво, період XIX-XX століть та сучасний період. Кожен етап відзначається появою величних храмів, які $\epsilon$ яскравими домінантами в архітектурному просторі поселень та створюють неповторний сакральний образ Тернопільської області.

Показано, щзо на досліджуваній території майже не залишилось священних предметів ранньосередньовічного періоду, крім курганів та печерних храмів. Високе Середньовіччя представлено одиничними храмами. Період Відродження декларує прийняття західносвропейських будівельних технологій. Храми мають яскраво виражену захисну функиію. Найяскравіше Тернопільщина представлена Бароковими храмами епохи Просвітництва. Період XIX-XX ст. ознаменований пошуками національного стилю в сакральній архітектурі. Сучасні храмові комплекси будуються за традииійною системою планування, але деякі мають сучасні форми.

Ключові слова: сакральна архітектура, храмові комплекси, сакральний образ, архітектурний стиль. 